Research Report No. 9/2006

\title{
Spaces and Places: A Systems Theory Approach to Regulatory Competition in European Company Law
}

Peer Zumbansen

Osgoode Hall Law School of York University, PZumbansen@osgoode.yorku.ca

Follow this and additional works at: http:// digitalcommons.osgoode.yorku.ca/clpe

\section{Recommended Citation}

Zumbansen, Peer, "Spaces and Places: A Systems Theory Approach to Regulatory Competition in European Company Law" (2006). Comparative Research in Law \& Political Economy. Research Paper No. 9/2006.

http://digitalcommons.osgoode.yorku.ca/clpe/168 


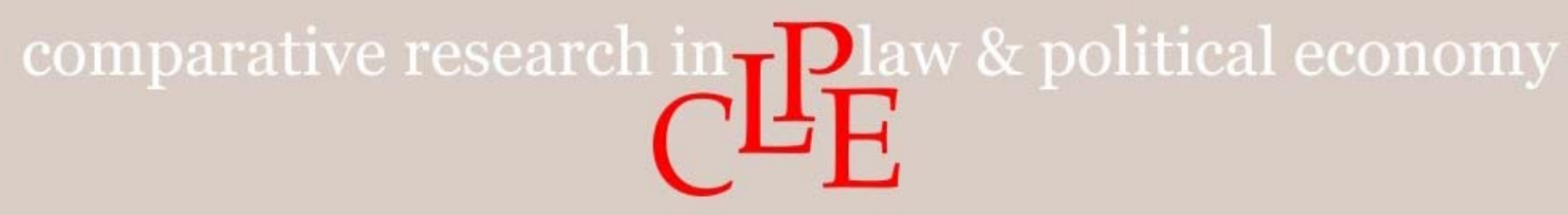

\section{Law Research Institute Research Paper Series}

CLPE Research Paper 9/2006

Vol. 02 No. 02 (2006)

Peer Zumbansen

SPACES AND PlaCES:

A SYSTEMS THEORY APPROACH TO

REGULATORY COMPETITION IN EUROPEAN COMPANY LAW

Forthcoming in: European Law Journal, Vol. 12, No. 4, July 2006

Author Contact: Prof. Peer Zumbansen

Canada Research Chair

Osgoode Hall Law School, York University

4700 Keele St., Toronto, Ontario M3J 1P3, Canada

Email: pzumbansen@osgoode.yorku.ca

This paper can be downloaded without charge from the

Social Science Research Network Electronic Library at:

http://ssrn.com/abstractid $=\mathbf{9 0 2 6 9 5}$

An index to the working papers in the

Comparative Research in Law and Political Economy

Research Paper Series is located at:

http://www.comparativeresearch.net

CLPE RPS Editors: John Cioffi (University of California at Riverside),

Peer Zumbansen (Osgoode Hall Law School, Toronto, Director,

Comparative Research in Law and Political Economy)

Production Editor: James Brink (Osgoode Hall Law School, Toronto) 

CLPE Research Paper 8/2006

Vol. 02 No. 02 (2006)

\title{
Peer Zumbansen
}

\section{Spaces and Places: A Systems Theory Approach to REGULATORY COMPETITION IN EUROPEAN COMPANY LAW}

\begin{abstract}
This article takes issue with the longstanding oppositional themes of harmonisation versus regulatory competition in European company law. Instead of embracing one approach over the other in exclusivity, the article draws attention to the persisting mixture of approaches to an emerging Europeanwide law regulating the business corporation. Against the background of an ongoing struggle over identifying the goals and taboos of the European legislator's mandate in regulating the company, the argument put forward here is that this very struggle is reflective of the nature of the evolution of company law in an 'integrating Europe and a globalising world'. European attempts of developing European company law as part of a larger initiative of improving the Union's potential for innovation and competition are thus likely to meet with the challenges that contemporary Nation States are facing when adapting their modes of regulation and representation to the demands of an increasingly complex and decentralised fields of market activities. Situating the law of the business corporation within the larger theme of European integration on the one hand, and of issues of market regulation, domestic, transnational, and international, on the other, suggests the adoption of a systems theory-based approach to understanding the boundaries of law in this multilevel and multipolar process.
\end{abstract}

Keywords: European Company Law; Regulatory Competition; Harmonization; Societas Europaea; Takeover Law; Corporate Governance.

Forthcoming in: European Law Journal, Vol. 12, No. 4, July 2006. 
CLPE Comparative Research in Law \& Political Economy

www.comparativeresearch.net

Osgoode Hall Law School, York University

4700 Keele St., Toronto, Ontario M3J 1P3, Canada

Email: pzumbansen@osgoode.yorku.ca 
Law is a scavenger. It grows by feeding on ideas from outside, not by inventing new ones of its own.

E. D. Elliott, (1985) 85 Columbia Law Review 38

The law is full of phraseology drawn from morals, and by the mere force of language continually invites us to pass from one to the other without perceiving it, as we are sure to do unless we have the boundary constantly before our minds.

O. W. Holmes Jr., (1897)10 Harvard Law Review 457, 459-460

\section{CORPORATE GOVERNANCE, EUROPEAN INTEGRATION, AND GLOBAL MARKETS}

The process of European company law harmonisation offers itself as a case in point for an inquiry into the intricate process of European integration. At the same time, it illustrates the nature of legal evolution as reflected in the increasingly multilevel and trans-territorialised norm production in the law of corporate governance. On the one hand, business has for a long time now come to be organised in a globe-spanning manner, with historically strong attempts to liberate itself of Nation States' regulatory aspirations or constraints. ${ }^{1}$ This is part of the Nation

\footnotetext{
${ }^{1}$ C. Schmitthoff, 'International Business Law: A New Law Merchant', (1961) 2 Current Law and Social Problems 129-153; J.-P. Robé, 'Multinational Enterprises: The Constitution of a Pluralistic Legal Order', in G. Teubner (eds.), Global Law Without A State (Aldershot, 1997); F. D. Ly, 'Lex Mercatoria (New Law Merchant): Globalisation and International SelfRegulation', in V. Gessner,R. P. Appelbaum and W. F. Felstiner (eds.), Rules and Networks. The Legal Culture of Global Business Transactions (Hart Publishing, 2001); A. C. Cutler, Private Power and Global Authority: Transnational Merchant Law in the Global Economy (Cambridge University Press, 2003)
} 
State's larger struggle over regulatory sovereignty with regard to the economic processes that unfold within and beyond national borders. On the other hand, however, corporations remain, in many respects, embedded in a complex field of historically grown, institutionally and legally structured frameworks of national regulation and administration. ${ }^{2}$ National corporate laws are embedded in distinct socio-economic cultures, historically grown legal and industrial régimes. Scholars in comparative corporate governance have become increasingly aware of the methodological challenges in comparing different corporate governance régimes. After early critiques of a functional approach to comparative law, ${ }^{3}$ comparative legal scholarship has become much more nuanced, contextualised, and differentiated. ${ }^{4}$ Contemporary works place great emphasis on the particular cultures of corporate governance

\footnotetext{
${ }^{2}$ M. O'Sullivan, 'Corporate Governance and Globalization', (2000) 570 The Annals of The American Academy of Political and Social Science [ANNALS] 153-172; J. W. Cioffi/S. S. Cohen, 'The state, law and corporate governance: the advantage of forwardness', in S. S. Cohen and G. Boyd (eds.), Corporate Governance and Globalization. Long Range Planning Issues (Edward Elgar, 2000); that 'culture' matters greatly, has been acknowledged widely, see only B. R. Cheffins, 'Current Trends in Corporate Governance: Going from London to Milan via Toronto', (1999) 10 Duke J. Comp. \& Int'l L. 5-42; J. Fanto, 'The Role of Corporate Law in French Corporate Governance', (1998) 31 Cornell Int'l L.J. 31-91; R. Buxbaum/K. J. Hopt, Legal Harmonization and the Business Enterprise. Corporate and Capital Market Law Harmonization Policy in Europe and the U.S.A. (Walter de Gruyter, 1988); K. J. Hopt, 'Common Principles of Corporate Governance in Europe?' in J. A. McCahery,P. Moerland,T. Raaijmakers and L. Renneborg (eds.), Corporate Governance Regimes. Convergence and Diversity (Oxford University Press, 2002); Á. R. Oquendo, 'Breaking on Through to the Other Side: Understanding European Corporate Governance', (2001) 22 U. Pa. Intl'l Econ. L. 975-1027, 976.

3 J. Hill, 'Comparative Law, Law Reform and Legal Theory', (1989) 9 Oxford Journal of Legal Studies 101-115.

4 See for example the helpful study by W. W. Bratton/J. A. McCahery, 'Comparative Corporate Governance and Barriers to Global Cross Reference', in J. A. McCahery,P. Moerland,T. Raaijmakers and L. Renneborg (eds.), Corporate Governance Regimes. Convergence and Diversity (Oxford University Press, 2002).
} 
norms, the role of institutions, policies, path dependency, and innovation: ${ }^{5}$

Corporate governance practices are partly cultural and historical products. In this context, culture can be defined as the conceptual framework whereby individuals, generally of the same country, understand and mediate the pressures of the world and motivate as well as explain their actions. As the corporation is a meaningful and purposeful human response to economic and social pressures, culture clearly informs corporate governance practices. ${ }^{6}$

The considerably short history of European company law contains much evidence of this. In spite of a strong push for streamlining in some areas, particularly in capital market law due to increased demands for transparency and more efficient management control, it is likely that national obstacles will continue to crowd the route towards a European wide company law. European company law reflects the persisting challenges to European integration in that it

${ }^{5}$ See foremost M. J. Roe, 'Path Dependence, Political Options and Governance Systems', in K. J. Hopt and E. Wymeersch (eds.), Comparative Corporate Governance. Essays and Materials (Walter de Gruyter, 1997).

${ }^{6}$ J. Fanto, 'The Role of Corporate Law in French Corporate Governance', (1998) 31 Cornell Int'l L.J. 31-91, at 36.

${ }^{7}$ Most recently L. Enriques, 'Company Law Harmonization Reconsidered: What Role for the EC?' (2005) ECGI Law Working Paper No. 53/2005 (November) http://ssrn.com/abstract=850005; G. Hertig/J. A. McCahery, 'An Agenda for Reform: Company and Takeover Law in Europe', in G. Ferrarini,K. J. Hopt,J. Winter and E. Wymeersch (eds.), Reforming Company and Takeover Law in Europe (Oxford University Press, 2004), 24: “...EU Company law can be viewed largely as an incomplete and rather ineffective set of provisions." See already K. J. Hopt, 'Europäisches Gesellschaftsrecht Krise und neue Anläufe', (1998) 43 Die Aktiengesellschaft (AG) 96-106; K. J. Hopt, 'Common Principles of Corporate Governance in Europe?' in J. A. McCahery,P. Moerland,T. Raaijmakers and L. Renneborg (eds.), Corporate Governance Regimes. Convergence and Diversity (Oxford University Press, 2002); A. Rebérioux, 'European Style of Corporate Governance at the Crossroads: The Role of Worker Involvement', (2002) 40 Journal of Common Market Studies 111-134; P. Zumbansen, 'European Corporate Law and National Divergences: The Case of Takeover Law', (2004b) 3 Wash. U. Glob. Stud. L. Rev. 867-886; J. S. Knudsen, 'Is the Single Market an Illusion? Obstacles to Reform of EU Takeover Regulation', (2005) 11 European Law Journal 507-524, 515. 
highlights the difficulties of creating a body of law for social actors who have been relying on national rules, institutions, and customs within the Nation State. ${ }^{8}$ The parallel efforts of realising the freedom of establishment and the free movement of capital through both the European legislator and the European Court of Justice ${ }^{9}$ have created a wide range of European-wide applicable rules. ${ }^{10}$ However, this process has at the same time consistently highlighted the immense political and socio-economic obstacles growing out of Member States' different 'models of capitalism', often associated with substantive costs in bringing about an

${ }^{8}$ See only F. Kübler, 'The Rules of Capital Under Pressure of the Securities Markets', in K. J. Hopt and E. Wymeersch (eds.), Capital Markets and Company Law (Oxford University Press, 2003), 100-101.

9 See below notes $53 \mathrm{ff}$ and accompanying text for a discussion of the Centros (1999), Überseering (2002) and Inspire Art (2003) decisions of the European Court of Justice. See hereto E. Wymeersch, 'Centros: A Landmark Decision in European Company Law', in T. Baums,K. J. Hopt and N. Horn (eds.), Corporations, Capital Markets and Business in the Law. Liber Amicorum Richard M. Buxbaum (Kluwer Law International, 2000); W. F. Ebke, 'The 'Real Seat' Doctrine in the Conflict of Corporate Laws', (2002) 36 The International Lawyer 1015-1037; W.-H. Roth, 'From Centros to Ueberseering: Free Movement of Companies, Private International Law, and Community Law', (2003) 52 ICLQ 177-208; C. Kersting/C. C. Schindler, 'The ECJ's Inspire Art Decision of 30 September 2003 and its Effects on Practice', (2003) 4 German Law Journal 1277-1291.

10 See the overview and analysis by J. Wouters, 'European Company Law: Quo Vadis?' (2000) 37 Common Market Law Review 257-307; recently S. Grundmann, Europäisches Gesellschaftsrecht. Eine systematische Darstellung unter Einbeziehung des Kapitalmarktrechts (C.F. Müller, 2004); see also the constantly updated website of the EU: http://europa.eu.int/comm/internal_market/en/company/company/official/.

${ }^{11}$ Most recently: J. S. Knudsen, 'Is the Single Market an Illusion? Obstacles to Reform of EU Takeover Regulation', (2005) 11 European Law Journal 507-524, 524; see already the intricate critique by M. Rhodes/B. v. Apeldoorn, 'Capital Unbound? The Transformation of European corporate governance', (1998) 5 Journal of European Public Policy 406-427 (reprinted in Thomas Clarke, ed., Theories of Corporate Governance. The Philosophical Foundations of Corporate Law (London/New York: Routledge, 2004), 243; A. Rebérioux, 'European Style of Corporate Governance at the Crossroads: The Role of Worker Involvement', (2002) 40 Journal of Common Market Studies 111-134. For a recent exposition of the "Models of Capitalism", see C. Crouch, 'Models of Capitalism', (2005) 10 New Political Economy 439-456. 
effective regulatory régime for companies operating and investing on the European market. ${ }^{12}$

In this article I will argue that the varied developments that characterise the evolution of European company law must be seen in correlation with the ambiguities in the EU's general struggle over its normative identity, its institutional and procedural design, and its larger political and constitutional future (I). Two alternative and competing approaches to explain the progress of European company law, namely harmonization and regulatory competition, will be critiqued as offering only an insufficient explanation for the particular obstacles faced by European company law. The political economy of European company law will be analysed against the background of the deep embeddedness of company law rules in national legal systems on the one hand, and their increasing erosion through a transnational law of corporate governance that is predominantly driven by capital market and securities law concerns on the other (II). The third part of the article explores the quality of the legal challenge to European integration and to European company law with regard to the larger transformation of regulatory instruments. In studying how the emergence of private law-making increasingly illuminates our understanding of law itself, its normative authority, and its 'boundaries', ${ }^{13}$ it becomes apparent how both the process of

${ }^{12}$ G. Hertig, 'Western Europe's Corporate Governance Dilemma', in T. Baums,K. J. Hopt and N. Horn (eds.), Corporations, Capital Markets and Business in the Law. Liber Amicorum Richard M. Buxbaum (Kluwer Law International, 2000); G. Hertig/J. A. McCahery, 'An Agenda for Reform: Company and Takeover Law in Europe', in G. Ferrarini,K. J. Hopt,J. Winter and E. Wymeersch (eds.), Reforming Company and Takeover Law in Europe (Oxford University Press, 2004), 39-40; F. Kübler, 'The Rules of Capital Under Pressure of the Securities Markets', in K. J. Hopt and E. Wymeersch (eds.), Capital Markets and Company Law (Oxford University Press, 2003), 101-103; L. Enriques, 'Company Law Harmonization Reconsidered: What Role for the EC?' (2005) ECGI Law Working Paper No. 53/2005 (November) http://ssrn.com/abstract=850005, 16-22.

${ }^{13}$ N. Luhmann, Law as a Social System (K.Ziegert transl., F.Kastner, D.Schiff, R.Nobles, R.Ziegert eds.) (Oxford University Press, 2004). 
European integration and European company law are situated in the broader context of studying the role of law in transnational regulatory contexts (III). 


\section{A European Integration and Globalization}

The most important general legal questions, it seems to me, both in theory and in practice, concern, first, the nature of the relationship between a society and the legal rules that operate within it, and, second, the forces that cause law to change.

\section{A. Watson, (1982) 131 University of Philadelphia Law Review}

While many problems inherent to the building of a large and complex polity remain, such as the genesis of rights based on membership or individual freedom, ${ }^{14}$ the process of European integration does not take place within a spatial void. Our focus on the place in which European integration takes place must not make us blind to the forces that shape the space 'Europe', as it is part of processes of global economic integration, political struggle over dominance and power, cultural identity and, importantly, the rule of law. In an era of globalisation, the EU's ongoing struggle over the role of law is mirrored by the threat that follows from the trans-territorialisation of societal activities. ${ }^{15}$ As already aptly perceived by Niklas Luhmann in the $1970{ }^{16}$ the law faces a particular challenge in the attempt to address its own capacities when dealing with extra-territorial incidents and processes. With societal activities unfolding in what has become a global society, ${ }^{17}$ the law as a particularly differentiated, historically emerged and institutionally embedded mechanism of stabilising social

\footnotetext{
${ }^{14}$ Excellent hereto: U. Haltern, 'Integration Through Law', in T. Diez and A. Wiener (eds.), European Integration Theory (Oxford University Press, 2004), at 188-191; H. Lindahl, 'European Integration: Popular Sovereignty and a Politics of Boundaries', (2000) 6 European Law Journal 239-256, at 243-4.

${ }^{15}$ S. Sassen, 'Globalization or denationalization?' (2003) 10 Rev. Int'l Pol. Econ. 1-22.

${ }^{16}$ N. Luhmann, 'Die Weltgesellschaft', (1970) 57 Archiv für Rechts- und Sozialphilosophie 1.

${ }^{17}$ See Fischer-Lescano, Globalverfassung. Die Geltungsbegründing der Menschenrechte im postmodernen ius gentium (Velbrück Wissenschaft, 2005).
} 
expectations by providing time-binding norms, is threatened to lose the very foundations on which it could so far perform its fragile function. ${ }^{18}$

\section{B European Company Law in the Process of European Integration}

In the 'European company law scene', ${ }_{1}^{19}$ the discussion has evolved dramatically since its early beginnings with the European Economic Communities. ${ }^{20}$ Studying the development of European

\footnotetext{
${ }^{18}$ This is reiterated in the last chapter of N. Luhmann, Law as a Social System (K.Ziegert transl., F.Kastner, D.Schiff, R.Nobles, R.Ziegert eds.) (Oxford University Press, 2004).

${ }^{19}$ C. Schmitthoff, 'The Future of the European Company Law Scene', in C. Schmitthoff (eds.), The Harmonisation of European Company Law (The U.K. Nat'l. Committee of Comparative Law, 1973).
}

20 Schwartz, 'Zur Konzeption der Rechtsangleichung in der Europäischen Wirtschaftsgemeinschaft', in (eds.), Festschrift für Walter Hallstein 1966); D. Vagts, 'Reforming the 'Modern Corporation': Perspectives from the German', (1966) 80 Harvard Law Review 23-89; E. v. Caemmerer, 'Europäische Aktiengesellschaft', in K. H. Biedenkopf,H. Coing and E.-J. Mestmäcker (eds.), Das Unternehmen in der Rechtsordnung. Festgabe für Heinrich Kronstein aus Anlass seines 70. Geburtstages am 12.9.1967 (C.F.Müller, 1967); P. Leleux, 'Harmonisation des droits des sociétés', in E. von Caemmerer (eds.), Europäische Handelsgesellschaft und Angleichung des nationalen Gesellschaftsrechts. Wissenschaftliches Kolloquium der Fachgruppe Europarecht Wissenschaftliche Gesellschaft für Europarecht - am 5./6.Mai 1967 in Bad Ems (Alfred Metzner, 1968); M. Lutter, 'Die Rechtsangleichung im Gesellschaftsrecht', in E. von Caemmerer (eds.), Europäische Handelsgesellschaft und Angleichung des nationalen Gesellschaftsrechts. Wissenschaftliches Kolloquium der Fachgruppe Europarecht Wissenschaftliche Gesellschaft für Europarecht - am 5./6.Mai 1967 in Bad Ems (Alfred Metzner, 1968); C. W. A. Timmermans, 'Die europäische Rechtsangleichung im Gesellschaftsrecht. Eine integrations- und rechtspolitische Analyse', (1984) 48 RabelsZ 147; R. Buxbaum/K. J. Hopt, Legal Harmonization and the Business Enterprise. Corporate and Capital Market Law Harmonization Policy in Europe and the U.S.A. (Walter de Gruyter, 1988); K. v. Hulle, 'The Harmonisation of Company Law in the European Community', in B. Wachter,K. van Hulle,W. Landau,J. R. Schaafsma and M. Raaijmakers (eds.), Harmonisation of company and securities law. The European and American approach (Tilburg University Press, 1989); D. Charny, 'Competition among Jurisdictions in Formulating Corporate Rules: An American Perspective on the "Race to the Bottom" in the European Communities', (1991) 32 Harvard International Law Journal (Harv. Int'l L.J.) 423-456; R. J. Gilson, 'The Political Ecology of Takeovers: Thoughts on Harmonizing the 
company law over the past few decades reveals a wealth of institutional histories, discourses and blockades, national pathdependencies, and an increasing push from the world around to adapt some baselines of company law and securities law in Europe to international standards. That this discussion has been continuing predominantly with regard to the term 'corporate governance' is a telling fact. The term corporate governance has increasingly come to encompass all bodies of law applicable to the modern business corporation. Yet, a confined understanding of the term would focus on the rules that govern the distribution and exercise of power and control of management and shareholders in a large, publicly held corporation. Expanding this focus, a wider, more far-reaching term would aim at capturing the complex interplay of various bodies of law as they shape the regulatory

European Corporate Governance Environment', in K. J. Hopt and E. Wymeersch (eds.), European Takeovers. Law and Practice (Butterworths, 1992); A. Dorresteijn/I. Kuiper/G. Morse, European Corporate Law (Kluwer, 1994); G. A. Bermann, 'Harmonization and Regulatory Federalism', in I. Pernice (eds.), Harmonization of Legislation in Federal Systems (Nomos, 1996); H. J. Goldschmidt, 'Harmonization of Corporate Law in Federal Systems: A United States Perspective - Comments', in I. Pernice (eds.), Harmonization of Legislation in Federal Systems (Nomos, 1996); V. Edwards, EC Company Law (Oxford University Press, 1999); J. Wouters, 'European Company Law: Quo Vadis?' (2000) 37 Common Market Law Review 257-307; G. Hertig, 'Western Europe's Corporate Governance Dilemma', in T. Baums,K. J. Hopt and N. Horn (eds.), Corporations, Capital Markets and Business in the Law. Liber Amicorum Richard M. Buxbaum (Kluwer Law International, 2000); S. Deakin, 'Regulatory Competition versus Reflexive Harmonisation in European Company Law', in D. C. Esty and D. Geradin (eds.), Regulatory Competition and Economic Integration. Comparative Perspectives (Oxford University Press, 2001); M. Habersack, Europäisches Gesellschaftsrecht, 2. Aufl. (C.H.Beck, 2003) ('1999); K. Heine/W. Kerber, 'European Corporate Laws, Regulatory Competition and Path Dependence', (2002) 13 European Journal of Law and Economics 47-71; K. J. Hopt, 'Modern Company Law and Capital Market Problems. Improving European Corporate Governance after Enron', (2002) ECGI Working Paper Series in Law, WP No. 05/2002 at www.oecd.org/dataoecd/21/28/1857275.pdf; L. Enriques, 'Company Law Harmonization Reconsidered: What Role for the EC?' (2005) ECGI Law Working Paper No. 53/2005 (November) http://ssrn.com/abstract=850005; E. Wymeersch, 'About Techniques of Regulating Companies in the European Union', in G. Ferrarini,K. J. Hopt,J. Winter and E. Wymeersch (eds.), Reforming Company and Takeover Law in Europe (Oxford University Press, 2004). 
reality of the corporation. ${ }^{21}$ Among these bodies of law, one will have to consider company/corporate law, securities law, labour and employment law, tax law as well as the larger field of rules relating to industrial relations, co-determination, vocational training, and even environmental protection..$^{22}$ The term 'corporate governance', meandering between such narrow and wide meanings, reminds us thus of much older debates over the nature of the business corporation and its role in society. ${ }^{23}$ As will become clear in the following pages, these perennial issues accompany even the present debates in European company law.

Not that the task of developing European company law ever was an easy one to begin with. ${ }^{24}$ The diversification of company law

21 P. A. Gourevitch/J. Shinn, Political Power and Corporate Control. The New Global Politics of Corporate Governance (Princeton University Press, 2005), 2: "Corporate Governance systems reflect public policy choices." See also R. Kraakman/P. L. Davies/H. Hansmann/G. Hertig/K. J. Hopt/H. Kanda/E. B. Rock, The Anatomy of Corporate Law. A Comparative and Functional Approach (Oxford University Press, 2004), 67-8.

${ }^{22}$ P. Zumbansen, 'The Parallel Worlds of Corporate Governance and Labor Law', 13 Indiana Journal of Global Studies forthcoming

${ }^{23}$ See, for example, the classical debate between Berle and Dodd: A. A. Berle, 'Corporate Powers as Powers in Trust', (1931) 44 Harvard Law Review 1049-1074; E. M. Dodd, 'For Whom are Corporate Managers Trustees?' (1932) 45 Harvard Law Review 1145-1163; A. A. Berle, 'For Whom Corporate Managers are Trustees', (1931) 45 Harvard Law Review 13651372; see, later, A. A. Berle, The 20th Century Capitalist Revolution (Harcourt, Brace \& World, 1954). In Germany, see above all the still breathtaking study by W. Rathenau, Vom Aktienwesen (S. Fischer, 1918); see later, for example, G. Teubner, 'Unternehmensinteresse das gesellschaftliche Interesse des Unternehmens "an sich"?' (1985) 149 ZHR 470-488; for a discussion of these debates and their contemporary recurrence, see P. Zumbansen, Innovation und Pfadabhängigkeit. Das Recht der Unternehmensverfassung in der Wissensgesellschaft (Habilitation thesis, University of Frankfurt) forthcoming)Ch. 1.

${ }^{24}$ C. Schmitthoff, 'The Future of the European Company Law Scene', in C. Schmitthoff (eds.), The Harmonisation of European Company Law (The U.K. Nat'l. Committee of Comparative Law, 1973); C. W. A. Timmermans, 'Die europäische Rechtsangleichung im Gesellschaftsrecht. Eine integrations- und rechtspolitische Analyse', (1984) 48 RabelsZ 147; C. W. A. Timmermans, 'Harmonization in the Future of Company Law in Europe', in K. J. Hopt and E. Wymeersch (eds.), Capital Markets and Company Law (Oxford University Press, 2003). 
into a larger research field of corporate governance renders the EC's agenda in the field of European company law even more difficult. While the Enron, WorldCom and TyCo earthquakes have shaken up the legal and political consciousness worldwide, ${ }^{25}$ Europe not only discovers its own dead bodies (Ahold, Parmalat), but continues to face serious obstacles on its way to further consolidating company and securities law rules across an enlarged Europe of twenty-five Member States. ${ }^{26}$ With the dramatic moves undertaken by Brussels in the past years towards developing company and securities law as vital pillars of an overall attempt to improve Europe's international competitiveness, ${ }^{27}$ there have been numerous initiatives on the domestic and the European level to further outline the challenges and obstacles for a European company law. ${ }^{28}$ Just as the Enron shock was to make its way across the Atlantic and frantic attempts unfolded to persuade the DC lawmakers to refrain from issuing listing rules for the New York Stock Exchange that would likely prove incompatible with

${ }^{25}$ See the excellent account by W. W. Bratton, 'Enron and the Dark Side of Shareholder Value', (2002) 76 Tul. L. Rev. 1275-1361; S. Deakin/S. J. Konzelmann, 'Learning from Enron', (2004) 12 Corporate Governance 134-142.

${ }^{26}$ See hereto the contributions in Bermann/Pistor (eds.), Law and Governance in an Enlarged Union (Hart Publishing, 2004).

${ }^{27}$ EU-Commission, 'Communication from the Commission to the Council and the European Parliament: Modernising Company Law and Enhancing Corporate Governance in the European Union - A plan to move forward, 21 May 2003, COM (2003) 284, 6', (2003) http://europa.eu.int/eur-lex/eng/com/cnc/2003/com2003_0284de01.pdf.

${ }^{28}$ See, for an excellent overview (dating from 2002), E.-M. Kieninger, Wettbewerb der Rechtsordnungen im Europäischen Binnenmarkt (Mohr Siebeck, 2002); S. Mock, 'Harmonization, Regulation and Legislative Competition in European Corporate Law', in: 20023 German Law Journal, available at: http://www.germanlawjournal.com/current_issue.php?id=216; more recently: S. Grundmann, Europäisches Gesellschaftsrecht. Eine systematische Darstellung unter Einbeziehung des Kapitalmarktrechts (C.F. Müller, 2004); P. Zumbansen, 'European Corporate Law and National Divergences: The Case of Takeover Law', (2004b) 3 Wash. U. Glob. Stud. L. Rev. 867-886; for an overview of the EU's activities, see http://europa.eu.int/comm/internal_market/company/index_en.htm 
continental corporate governance rules, ${ }^{29}$ the EU was in the midst of facing its own corporate governance challenge.

The parallel deadlocks of adopting the statute for the Societas Europaea $(\mathrm{SE}),^{30}$ an attempt that had proven futile for three decades, and of passing a EU directive governing corporate takeovers in Europe, ${ }^{31}$ an undertaking that had already been brought on the way in $1989,,^{32}$ constituted serious problems for a European administration that-in tandem with many of its Member States-feverishly worked towards a level playing field of companies in Europe. Throughout the 1990s, it had increasingly seemed as if the process of European company law integration had

\footnotetext{
${ }^{29}$ N. Tollet, 'The Societas Europea: Europeanization via Americanization of Corporate Law. Corporate Governance: Only One Model?' (2005) 5 Global Jurist Topics Art. 3, at http://www.bepress.com/gj/topics/vol5/iss2/art3.

${ }^{30}$ E. Werlauff, 'The SE Company - A New Common European Company from 8 October 2004', (2003) 14 European Business Law Review [EBLR] 85-103; C. Teichmann, 'The European Company - A Challenge to Academics, Legislatures and Practitioners', in: 4 German Law Journal No. 4 (1 April 2003), pp. 309-330, available at: http:/www.germanlawjournal.com; V. Edwards, 'The European Company - Essential Tool or Eviscerated Dream?' (2003) 40 Common Market Law Review 443-464; S. Ebert, 'The European Company on the Level Playing Field of the Community', (2003) 14 European Business Law Review [EBLR] 183-192; T. L. Blackburn, 'The Societas Europea: The Evolving European Corporation Statute', (1993) 61 Fordham Law Review 695-772.

${ }^{31}$ B. Pettet, 'Private versus Public Regulation in the field of Takeovers: The Future under the Directive', (2000) European Business Law Review [EBLR] 381-388; K. J. Hopt, 'European Takeover Regulation: Barriers to and Problems of Harmonizing Takeover Law in the European Community', in K. J. Hopt and E. Wymeersch (eds.), European Takeovers. Law and Practice (Butterworths, 1992); R. J. Gilson, 'The Political Ecology of Takeovers: Thoughts on Harmonizing the European Corporate Governance Environment', in K. J. Hopt and E. Wymeersch (eds.), European Takeovers. Law and Practice (Butterworths, 1992); Zumbansen (2004b), supra.

32 T. Raaijmakers, 'Takeover Regulation in Europe and America: The Need for Functional Convergence', in J. A. McCahery,P. Moerland,T. Raaijmakers and L. Renneborg (eds.), Corporate Governance Regimes. Convergence and Diversity (Oxford University Press, 2002).
} 
lost its momentum. ${ }^{33}$ Finally, with the breakthrough at the 2000 Nice Summit for the SE statute, which subsequently got adopted in 2001 and went into force in October 2004, on the one hand, and with the all-exhausting passage of an eventually, much watereddown Takeover Directive ${ }^{34}$ by the European Parliament in December 2003, on the other, this long persisting stasis seemed to have come to an end. Moreover, the European Commission had seized upon the widespread uneasiness with the state of affairs to install an expert commission, whose first mandate had been to extrapolate the existing resistances against a European takeover régime and to develop a model that would be likely to satisfy the opponents. ${ }^{35}$ With the group of experts, under the direction of Dutch law professor, Jaap Winter, presenting the report in admirably short time, the group received a follow-up mandate, which might be seen as the starting point of a new phase in European company lawmaking: the group, again directed by Winter, launched a comprehensive online consultation on an outline for a 'Modernized Company Law in Europe'-three months after presenting the first report to the public. ${ }^{36}$ The second report by the High Level Group was made available after a careful analysis of the input from the online consultation in November 2002. ${ }^{37}$ Soon after, in May 2003, the European Commission issued

33 J. Wouters, 'European Company Law: Quo Vadis?' (2000) 37 Common Market Law Review 257-307.

34 S. Maul/A. Kouloridas, 'The Takeover Bids Directive', (2004) 5 German Law Journal 355-366, at http://www.germanlawjournal.com/pdf/.Vol05No04/PDF_Vol_05_No_04_355366_Private_Maul_Kouloridas.pdf

35 J. Winter, 'Report of the High Level Group of Company Law Experts on Issues related to Takeover Bids', (2002)

http:/europa.eu.int/comm/internal_market/company/docs/takeoverbids/2002-01-hlgreport_en.pdf.

${ }^{36} \mathrm{See}$ http://europa.eu.int/comm/internal_market/en/company/company/modern/index.htm.

${ }^{37}$ See J. Winter, 'Report of the High Level Group of Company Law Experts on A Modern Regulatory Framework for Company Law in Europe', (2002) at http://europa.eu.int/comm/internal_market/en/company/company/modern/consult/report_en. pdf. 
its Communication to the Council and the European Parliament: 'Modernising Company Law and Enhancing Corporate Governance in the European Union - A Plan to Move Forward' ('Action Plan'). ${ }^{38}$

In the two years since the Commission's Action Plan, the Commission has brought on the way a number of initiatives that build on the detailed programme laid out in 2003..$^{39}$ These initiatives are developed against the background of intense reform debates in the various Member States, not only with regard to the apparently inevitable move towards independent directors as mandated by the USA's 2002 Sarbanes-Oxley Act, ${ }^{40}$ but also in light of increasing pressure on existing systems of corporate management and industrial relations, in particular Germany's model of co-determination. ${ }^{41}$ These activities increasingly unfold in a complex regulatory environment of state-set statutory law on the one hand, and of norms produced by expert commissions,

\footnotetext{
${ }^{38}$ Available at: http://europa.eu.int/eur-lex/en/com/cnc/2003/com2003_0284en01.pdf.

39 For an updated overview, see http://europa.eu.int/comm/internal market/company/index en.htm and http://europa.eu.int/comm/internal_market/company/ecgforum/index_en.htm.

${ }^{40} \mathrm{~J}$. N. Gordon, 'Governance Failures of the Enron Board and the New Information Order of Sarbanes-Oxley', (2003) Harvard John M. Olin Center for Law, Economics, and Business, Discussion Paper No. 416 (April), papers.ssrn.com/sol3/papers.cfm?abstract_id=391363 at http://www.law.columbia.edu/center_program/law_economics/wp_listing_1/wp_author?excl usive=filemgr.download\&file_id $=69105 \&$ rtcontentdisposition=filename\%3DWP216.pdf
}

, R. Thompson, 'Corporate Governance After Enron: The First Year', (2003) Vanderbilt University Law School, Law \& Economics, Working Paper No. 03-13, papers.ssrn.com/sol3/papers.cfm?abstract_id $=429622$ at www.ssrn.com

${ }^{41}$ See, e.g., T. Baums, 'Interview: Reforming German Corporate Governance: Inside a Law Making Process of a very new nature', (2001) 2 German Law Journal at: http://www.germanlawjournal.com/past_issues.php?id=43; K. J. Hopt, 'Corporate Governance in Germany', in K. J. Hopt and E. Wymeersch (eds.), Capital Markets and Company Law (Oxford University Press, 2003); see also J. Dammann, 'The Future of Codetermination after Centros: Will German Corporate Law move closer to the U.S. Model?' (2003) 8 Fordham Journal of Corporate \& Financial Law 607. 
think-tanks, quasi-public regulatory bodies, and private corporations on the other. ${ }^{42}$ That the European legislator should concern itself with issues as precarious and contested as executive compensation, ${ }^{43}$ while the Court of Justice marches on with increasing pressure on Member States' rules on company seats, ${ }^{44}$ are clear signs of an ever-faster diversifying agenda for Brussels' European company law programme.

Any attempt, therefore, at rendering an adequate picture of European company law making has to start from the premise that such rules are now developed in and emerging from a multilevel process of norm-production. With this, a study of European company law necessarily has to take into consideration the impact of different localities and types of norm-production on the emergence of European wide rules and standards, but also the persisting patterns of political opposition against reform..$^{45}$ The German rules governing worker participation in business

42 Hereto, see P. Zumbansen, Innovation und Pfadabhängigkeit. Das Recht der Unternehmensverfassung in der Wissensgesellschaft (Habilitation thesis, University of Frankfurt) forthcoming); see also the overview of corporate governance codes in Europe, issued and constantly updated by the European Corporate Governance Institute (ECGI), at http://www.ecgi.org/.

43 See the Commission Recommendation of 14 December 2004, available at: http://europa.eu.int/comm/internal_market/company/directors-remun/index_en.htm

${ }^{44}$ K. Bälz/T. Baldwin, 'The End of the Real Seat Theory (Sitztheorie): the European Court of Justice Decision in Ueberseering of 5 November 2002 and its Impact on German and European Company Law', in: No.12 3 German Law Journal, available at: http://www.germanlawjournal.com/current_issue.php?id=214; C. Kersting/C. C. Schindler, 'The ECJ's Inspire Art Decision of 30 September 2003 and its Effects on Practice', (2003) 4 German Law Journal 1277-1291; W. Bayer, 'Die EuGH-Entscheidung Inspire Art und die deutsche GmbH im Wettbewerb der europäischen Rechtsordnungen', (2003) BB 2357-2366.

${ }^{45}$ G. Hertig/J. A. McCahery, 'An Agenda for Reform: Company and Takeover Law in Europe', in G. Ferrarini,K. J. Hopt,J. Winter and E. Wymeersch (eds.), Reforming Company and Takeover Law in Europe (Oxford University Press, 2004), at 24; E. Wymeersch, 'About Techniques of Regulating Companies in the European Union', in G. Ferrarini,K. J. Hopt,J. Winter and E. Wymeersch (eds.), Reforming Company and Takeover Law in Europe (Oxford University Press, 2004). 
corporations have, in that respect, become a notorious example of a régime deeply embedded in the country's political economy. To touch on one part of the legal framework would likely result in a turmoil involving numerous other norms and institutions governing co-determination. ${ }^{46}$ Likewise, the described struggle over a European takeover régime did clearly reflect the complexities of a regulatory, socio-economic minefield made up of cultural predispositions, institutional traditions $\left(\right.$ Volkswagen $\left.^{4}\right)$ and established networks-all of which make any capital market laworiented reformer frown, at best. ${ }^{48}$

46 See, e.g., K. Pistor, 'Codetermination: A Sociopolitical Model with Governance Externalities', in M. Blair and M. J. Roe (eds.), Employees and Corporate Governance (Brookings Institution, 1999); M. J. Roe, 'German Co-Determination and German Securities Markets', in K. J. Hopt,H. Kanda,M. J. Roe,E. Wymeersch and S. Prigge (eds.), Comparative Corporate Governance. The State of the Art and Emerging Research (Oxford University Press, 1998); M. Weiss, 'Zur aktuellen Bedeutung des Mitbestimmungsurteils BVerfGE 50, 290 ff.' (2000) 83 Kritische Vierteljahresschrift für Gesetzgebung und Rechtswissenschaft 405-418.

${ }^{47}$ See the Commission's move against Germany with regard to the public holdings in the Volkswagen

Group: http://europa.eu.int/rapid/pressReleasesAction.do?reference=IP/03/410\&format=HTML\&ag ed=0 \&language=EN\&guiLanguage $=$ en; for a background, see J. Adolff, 'Turn of the Tide? The "Golden Share" Judgements of the European Court of Justice and the Liberalization of the European Capital Markets', in: 3 German Law Journal No. 8 (1 August 2002) available at: http://www.germanlawjournal.com/past_issues.php?id=170.

${ }^{48}$ C. Kirchner/R. W. Painter, 'Takeover Defenses under Delaware Law, the Proposed Thirteenth EU Directive and the New German Takeover Law: Comparison and Recommendations for Reform', (2002) 50 American Journal of Comparative Law 451-476. 


\section{HARMONIZATION VERSUS REGULATORY COMPETITION}

The struggle over the different reasons for resistance against the SE or a Europe-wide takeover régime was continuously fought out with regard to a seemingly inescapable set of methodological approaches, harmonisation, and its allegedly exclusive alternative, regulatory competition. ${ }^{49}$ But not only the history of the SE and the Takeover Directive have contributed to a more differentiated reading of these approaches. ${ }^{50}$ While the comparison of state competition in the USA and the different conflict of laws régime in the European Community had occupied theorists for the longest time, ${ }^{51}$ change eventually came about by the European Court of

49 See, e.g., K. Heine/W. Kerber, 'European Corporate Laws, Regulatory Competition and Path Dependence', (2002) 13 European Journal of Law and Economics 47-71; E. M. Kieninger, 'Rechtsentwicklung im Wettbewerb der Rechtsordnungen', in C. Ott and H.-B. Schäfer (eds.), Vereinheitlichung und Diversität des Zivilrechts in transnationalen Räumen (Mohr Siebeck, 2002); P. B. Stephan, 'The Futility of Unification and Harmonization in International Economic Law', (1999) Va. J. Int'l L. 743-797; S. Mock, 'Harmonization, Regulation and Legislative Competition in European Corporate Law', in: 20023 German Law Journal, available at: http://www.germanlawjournal.com/current_issue.php?id=216.

${ }^{50}$ G. Hertig/J. A. McCahery, 'An Agenda for Reform: Company and Takeover Law in Europe', in G. Ferrarini,K. J. Hopt,J. Winter and E. Wymeersch (eds.), Reforming Company and Takeover Law in Europe (Oxford University Press, 2004), 28: "By linking together mutual recognition of corporate law systems, subsidiarity [...] and minimum requirements, EU lawmakers have created a legal structure that supplies a degree of useful tension between regulatory competition and harmonization."

51 See, e.g. R. Buxbaum/K. J. Hopt, Legal Harmonization and the Business Enterprise. Corporate and Capital Market Law Harmonization Policy in Europe and the U.S.A. (Walter de Gruyter, 1988); P. Behrens, 'Krisensymptome in der Gesellschaftsrechtsangleichung', in U. Immenga,W. Möschel and D. Reuter (eds.), Festschrift für Ernst-Joachim Mestmäcker zum 70. Geburtstag (Nomos, 1996); D. Charny, 'Competition among Jurisdictions in Formulating Corporate Rules: An American Perspective on the "Race to the Bottom" in the European Communities', (1991) 32 Harvard International Law Journal (Harv. Int'l L.J.) 423-456; E.-M. Kieninger, Wettbewerb der Rechtsordnungen im Europäischen Binnenmarkt (Mohr Siebeck, 2002). 
Justice. The debate over the exportability of the US experience ${ }^{52}$ took a different turn in light of the European Court of Justice's Centros, ${ }^{53}$ Überseering, ${ }^{54}$ and Inspire Art ${ }^{55}$ rulings in 1999, 2002, and 2003. Leaving no doubt, the Inspire Art decision and the Court of Justice's ruling in Laysterie du Saillant ${ }^{56}$ of 2004 underscored what even the staunchest defenders of the seat theory and the impossibility of regulatory competition among Member States for corporate charters could no longer deny: that corporations were free to incorporate in any Member State and that their incorporation would have to be recognised in another Member

52 The literature is endless and continues to grow: W. L. Cary, 'Federalism and Corporate Law: Reflections Upon Delaware', (1974) 83 Yale Law Journal 663-705; R. K. Winter, 'State Law, Shareholder Protection, and the Theory of the Corporation', (1977) 6 Journal of Legal Studies 251-292; R. Romano, 'Law as Product: Some Pieces of the Incorporation Puzzle', (1985) 1 Journal of Law, Economics and Organizations 225-283; D. Charny, 'Competition among Jurisdictions in Formulating Corporate Rules: An American Perspective on the "Race to the Bottom" in the European Communities', (1991) 32 Harvard International Law Journal (Harv. Int'l L.J.) 423-456; L. A. Bebchuk, 'Federalism and the Corporation: The Desirable Limits on State Competition in Corporate Law', (1992) 105 Harvard Law Review 1437-1510; L. A. Bebchuk/A. Ferrell, 'Federalism and Takeover Law: The Race to Protect Managers from Takeovers', (1999) 99 Columbia Law Review 1168; E. M. Kieninger, 'Rechtsentwicklung im Wettbewerb der Rechtsordnungen', in C. Ott and H.B. Schäfer (eds.), Vereinheitlichung und Diversität des Zivilrechts in transnationalen Räumen (Mohr Siebeck, 2002); K. Heine, Regulierungswettbewerb im Gesellschaftsrecht. Zur Funktionsfähigkeit eines Wettbewerbs der Rechtsordnungen im europäischen Gesellschaftsrecht (Duncker \& Humblot, 2003).

${ }^{53}$ Case C-212/97, Centros Ltd. v. Erhvervs-Org., 1999 O.J. (C 136) 3.

${ }^{54}$ See Kilian Baelz \& Teresa Baldwin, The End of the Real Seat Theory (Sitztheorie): The European Court of Justice Decision in Ueberseering of 5 November 2002 and its Impact on German and European Company Law, in 3 German L.J. No.12 (2002), available at http://www.germanlawjournal.com/current_issue.php?id=214.

${ }^{55}$ Case C-167/01, Kamer van Koophandel en Fabriken voor Amsterdam v. Inspire Art Ltd., 2003 O.J. (C 275) 10, available at http:// europa.eu.int/smartapi/cgi/sga_doc?smartapi!celexapi!prod!CELEXnumdoc\&lg=

EN\&numdoc $=62001 \mathrm{~J} 016 \&$ model=guichett; see Kersting \& Schindler, The ECJ's Inspire Art Decision of 30 September and Its Effects on Practice, in 4 German L.J. No.12, 1277-91 (2003), available at http://www.germanlawjournal.com /article.php?id=344.

${ }^{56}$ C-9/02 of 11 March 2004. 
State. ${ }^{57}$ With this jurisprudence, the field had opened widely. The case law from Centros to Laysterie du Saillant gave powerful testimony of how deeply ingrained company law régimes were in the particular economic, political, and cultural history of the Member States. ${ }^{58}$ On their face, all cases dealt with the free movement of companies with regard to stated or alleged motives of escaping or circumventing certain minimum capital or tax requirements. While the minimum capital requirement goes to the heart of German corporate law for limited liability companies, ${ }^{59}$ it was clear to all that much more was at stake. The Court of Justice's masterful approach to the complexity of Member States' company law régimes baffled observers and commentators for years ${ }^{60}$ and while it now can be seen as a given that the EU sees an

${ }^{57}$ See hereto W. F. Ebke, 'Centros - Some Realities and Some Mysteries', (2000) 48 Am.J. Comp. L. 623; E. Wymeersch, 'Centros: A Landmark Decision in European Company Law', in T. Baums,K. J. Hopt and N. Horn (eds.), Corporations, Capital Markets and Business in the Law. Liber Amicorum Richard M. Buxbaum (Kluwer Law International, 2000); H. Halbhuber, 'National Doctrinal Structures and European Company Law', (2001) 38 Common Market Law Review 1385-1420; W.-H. Roth, 'From Centros to Ueberseering: Free Movement of Companies, Private International Law, and Community Law', (2003) 52 ICLQ 177-208; B. Seifert, "'Daily Mail", "Centros", "Überseering", "Inspire Art" - und kein Ende in Sicht!' (2003) GewArch 18-20; F. Wooldridge, 'Überseering: Freedom of Establishment of Companies Affirmed', (2003) 14 European Business Law Review [EBLR] 227-235.

${ }^{58}$ Zumbansen, Innovation und Pfadabhängigkeit, supra, Ch. 2, II.

${ }^{59}$ See only W. Bayer, 'Die EuGH-Entscheidung Inspire Art und die deutsche GmbH im Wettbewerb der europäischen Rechtsordnungen', (2003) BB 2357-2366; H. Eidenmüller, 'Wettbewerb der Gesellschaftsrechte in Europa (Besprechung des EuGH-Urteils "Überseering")', (2002) 23 ZIP 2233-2245; E. Schanze/A. Jüttner, 'Die Entscheidung für Pluralität: Kollisionsrecht und Gesellschaftsrecht nach der EuGH-Entscheidung "Inspire Art"', (2003) AG 661-671; for an intriguing perspective, see L. Enriques/J. Macey, 'Creditors Versus Capital Formation: The Case Against the European Legal Capital Rules', (2001) 86 Cornell Law Review 1165-1204.

${ }^{60}$ See only the references in H. Halbhuber, 'National Doctrinal Structures and European Company Law', (2001) 38 Common Market Law Review 1385-1420; K. Bälz/T. Baldwin, 'The End of the Real Seat Theory (Sitztheorie): the European Court of Justice Decision in Ueberseering of 5 November 2002 and its Impact on German and European Company Law', in: No.12 3 German Law Journal, available at: http://www.germanlawjournal.com/current_issue.php?id=214; C. Kersting/C. C. Schindler, 
emerging system of limited regulatory competition with regard to the free movement of capital, the undercurrents of this development become increasingly visible. In the aftermath of the case law pertaining to limited liability companies, the literature reflects on the climatic changes with regard to the chances of survival of national legal structures, in particular with regard to the law of corporate governance writ large. ${ }^{61}$

The history of European company law can thus be read as one of continued breaks, discontinuities, incremental, and revolutionary overhauls. While the Commission still speaks of harmonisation ${ }^{62}$ as an 'essential for creating a Single Market for Financial services and products', the experiences with the Societas Europaea, the Takeover Directive, and the free movement of companies case law from the Court of Justice suggests a differentiated reading of the term 'harmonisation', ${ }^{63}$ if not a fundamental disillusion. ${ }^{64}$ In the light of the complexity of institutions, rules, and values colliding in the just-described integration process, the opposition between harmonisation and regulatory competition seems to fall short of capturing the dimensions of today's regulatory spaces such as the EU. Instead of being governed neither exclusively by centralised

'The ECJ's Inspire Art Decision of 30 September 2003 and its Effects on Practice', (2003) 4 German Law Journal 1277-1291.

${ }^{61}$ See, for example, J. Dammann, 'The Future of Codetermination after Centros: Will German Corporate Law move closer to the U.S. Model?' (2003) 8 Fordham Journal of Corporate \& Financial Law 607; see the intriguing observations by E. Schanze/A. Jüttner, 'Die Entscheidung für Pluralität: Kollisionsrecht und Gesellschaftsrecht nach der EuGHEntscheidung "Inspire Art"', (2003) $A G$ 661-671 and W. F. Ebke, 'Überseering: "Die wahre Liberalität ist Anerkennung"', (2003) 58 JZ 927-933.

${ }^{62} \mathrm{http} / / /$ www.europa.eu.int/comm/internal_market/company/index_en.htm.

${ }^{63}$ See hereto M. Dougan, 'Vive la Différence? Exploring the Legal Framework for Reflexive Harmonisation Within the Single European Market', in R. A. Miller and P. Zumbansen (eds.), Annual of German \& European Law, Vol. I (2003) (Berghahn Books, 2004).

${ }^{64}$ L. Enriques, 'Company Law Harmonization Reconsidered: What Role for the EC?' (2005) ECGI Law Working Paper No. 53/2005 (November) http://ssrn.com/abstract=850005 
forces working towards the establishment of unified or compatible rules through harmonisation nor by an efficiency-driven process of a market battle over 'better rules', we find a multipolar and multilevel interplay of norm-production, political discourse, cultural, and socio-economic debate. ${ }^{65}$ In light of an increasingly laden research and policy agenda of European integration dynamics, ${ }^{66}$ on the one hand, and of the above described proliferation of corporate rules, on the other, little hope ought to be attached to an explanatory model that does not fully illuminate these dimensions. In reaching beyond both harmonisation and regulatory competition in their respective, exclusionary, and absolutist aspirations, we strive for being able to learn to adequately assess the wealth of institutional, procedural, and normative dimensions that characterises multipart and multilevel régimes of policy making.

${ }^{65}$ See already J. H. H. Weiler, 'The Transformation of Europe', (1991) Yale Law Journal 2403-2483; for a very rich analysis of Europe's multi-dimensional discourses, see V. Schmidt, The Futures of European Capitalism (Oxford University Press, 2002); V. Schmidt, 'Democracy and Discourse in an Integrating Europe and a Globalising World', (2005) 6 European Law Journal 277-300; see also C. Joerges, 'Deliberative Supranationalism - Two Defences', (2002) 8 European Law Journal 133-151; C. Joerges, 'The Law's Problems with the Governance of the European Market', in C. Joerges and R. Dehousse (eds.), Good Governance in Europe's Integrated Market (Oxford University Press, 2002); C. Landfried, Das politische Europa. Differenz als Potential der Europäischen Union (Nomos, 2002), 11, 55 , noting an expansion of integration goals beyond the common market; this can be observed in many different fields: see, e.g., V. Mayer-Schönberger, 'Governing Networks: Telecommunication Deregulation in Europe and the United States', (2002) 27 Brook. J. Int'l L. 819-851; G. Howells/T. Wilhelmsson, 'EC Consumer Law: Has it Come of Age?' (2003) 28 European Law Review 370-388; H. Callaghan, Battle of the systems of multi-level game? Domestic sources of Anglo-German quarrels over EU takeover law and worker consultation. Presentation at the 15th Annual Meeting of the Society for the Advancement of Socio-Economics, Aix-en-Provence, June 26-28, 2003, available at http://www.sase.org/conf2003/papers/callaghan_helen.pdf 2003).

${ }^{66}$ See the excellent overview and analysis by U. Haltern, 'Integration Through Law', in T. Diez and A. Wiener (eds.), European Integration Theory (Oxford University Press, 2004). 


\section{Undercurrents: European History, Globalization and the Unresolved Question of the EU's Nature}

The study of the dynamics between harmonisation and regulatory competition leads us back to the more fundamental questions regarding the ultimate goals of integration. Perhaps the company lawyer might have very little to say on this matter. At the same time, European company law can be understood as being so closely intertwined with the contested issues of economical and political integration. ${ }^{67}$ In this light, European company law reflects not only a field of law, but at the same time it is in itself an ongoing regulatory process that continues to challenge Member States and their respective company law systems. Indeed, this process has so far not given the final upper hand to either of the two approaches. Instead, the persisting dynamic of European company law development mostly results from the strong tensions among the different systems and the legal framework constraining either of the two poles in their ideal-type form. Being a veritable 'collision of systems ${ }^{\prime}{ }^{68}$ we would be well advised to take a yet closer look at many proclamations of universal convergence in the law of corporate governance. ${ }^{69}$ This is not to say that there are very

${ }^{67}$ E. Stein, 'International Integration and Democracy: No Love at First Sight', (2001) 95 American Journal of International Law (A.J.I.L.) 489-534; C. Joerges, 'The Impact of European Integration on Private Law: Reductionist Perceptions, True Conflicts and a New Constitutional Perspective', (1997) 3 European Law Journal 378-406; see now the contributions to Lynn Dobson/Andreas Follesdal (eds.), Political Theory and the European Constitution (Routledge, 2004); J. Scott/D. Trubek, 'Mind the Gap: Law and New Approaches to Governance in the European Union', (2002) 8 European Law Journal 1-18, D. Trubek/L. G. Trubek, 'Hard and Soft Law in the Construction of Social Europe: the Role of the Open Method of Coordination', (2005) 11 European Law Journal 343-364; Haltern (2004), supra note 14.

68 See for a recent exposition of this idea: A. Fischer-Lescano/G. Teubner, 'RegimeCollisions: The Vain Search for Legal Unity in the Fragmentation of Global Law', (2004) 25 Michigan J. Int'l L. 999-1046.

${ }^{69}$ See the critique by W. W. Bratton/J. A. McCahery, 'Comparative Corporate Governance and Barriers to Global Cross Reference', in J. A. McCahery,P. Moerland,T. Raaijmakers and 
distinct signs of an increasingly shareholder-oriented approach in corporate governance finding its way into worldwide company and securities law reform. The argument here is neither to reject this trend nor to condemn it outright. But Europe's very unique history of harmonisation/regulatory competition shows what is at stake in law reform with view to market demands and global integration. ${ }^{70}$ It is therefore worthwhile to keep a wider perspective on the issues of law reform in integrating market systems. Just as much as the nature of the emerging polity EU remains a matter of heated debate, the reach of corporate law directly touches on more fundamental issues regarding the place of the company in a wider regulatory environment. To disconnect corporate law and corporate law reform from other trends of legal and political reform would be to deny the corporation's embeddedness in a much larger context of regulatory change.

\section{The Political Economy of Harmonization versus REgUlATORY COMPETITION}

National legal meaning is in a different ballpark from European legal meaning. ${ }^{11}$

\section{A What Lies Beneath}

In this light, what would it mean to take a deeper look at harmonisation? From a harmonisation perspective, much of European law in its development and its adoption is closely monitored and analysed during the time of its inception.

L. Renneborg (eds.), Corporate Governance Regimes. Convergence and Diversity (Oxford University Press, 2002)

${ }^{70}$ Excellent hereto: P. B. Stephan, 'The Futility of Unification and Harmonization in International Economic Law', (1999) Va. J. Int'l L. 743-797; P. B. Stephan, 'The Political Economy of Choice of Law', (2002) 90 Georgetown Law Journal 957-970.

${ }^{71}$ Haltern (2004), supra note 14, at 192. 
Sometimes, this time will span over several years or, even decades, as was the case for the statute and Directive of the European Company or, still more recently, the Takeover Directive. In contrast, it is the time and the norms' fate after the adoption of the European instrument that often escapes our attention. It can thus be expected, that in order to study the (remaining) potential of harmonisation politics, much emphasis and effort must be given to engage in a deeper and more serious inquiry into how exactly this transformation unfolds in different Member States. ${ }^{72}$

Taking a closer look at the conceptualisation, adoption, and transformation of legal acts by the European lawmaker into the Member States' legal régimes might well illuminate the tricky process by which norms find their way into a particular existing legal environment. ${ }^{73}$ Taking an evolutionary approach to the study of legal development and of company law in particular allows for two things: first, this approach-as has been argued by Niklas Luhmann, ${ }^{74}$ and-with regard to company law in particular-by Mark Roe ${ }^{75}$ or Simon Deakin, ${ }^{76}$ refutes any idea of a linear, onedirectional allegedly efficiency-or coherence-driven development of legal norms. Instead, this approach considers historical and

\footnotetext{
${ }^{72}$ This approach is taken by a new, multi-year research project at the University of Vienna, directed by Thomas Bachner. This part of the paper represents my comments on his project, presented at the European Law Research Centre at Harvard Law School on 18 November 2004.

${ }^{73}$ G. Teubner, 'Legal Irritants: How Unifying Law Ends Up In New Divergences', in P. A. Hall and D. Soskice (eds.), Varieties of Capitalism. The Institutional Foundations of Comparative Advantage (Oxford University Press, 2001).

${ }^{74}$ N. Luhmann, 'Evolution und Geschichte', (1975) in: ders., Soziologische Aufklärung 2 150-169.

${ }^{75}$ M. J. Roe, 'Chaos and Evolution in Law and Economics', (1996) 109 Harv. L. Rev. 641668.

${ }^{76}$ S. Deakin, 'Evolution for our Time: A Theory of Legal Memetics', (2002) ESRC Centre for Business Research, University of Cambridge Working Paper No. 242 (also published in 55 Current Legal Problems 2002, pp.1-42) at www.cbr.cam.ac.uk/pdf/WP242.pdf
} 
political constellations and decisions that shaped particular developments. As these environments have been and continue to be in flux, legal development will always remain unpredictable to a certain degree. Second, an evolutionary approach can illuminate the very intricate forms in which norm collisions and norm reforms take place. Sometimes, they result from a veritable paradigm change or from the importation of foreign rules and principles, something that corporate governance scholars have been studying in the context of legal and economic reform projects in young or emerging democracies and transformation markets. ${ }^{77}$ But even in less dramatic circumstances, the transformation and translation of European law to the Member State level often produces a myriad of effects within the national legal order, ${ }^{78}$ laying bare the complexity of different co-evolving, social systems. $^{79}$ From that perspective, one may observe the introduction of a certain rule or standard, or as in the example of the optional co-determination régime of the Societas Europaea, ${ }^{80}$ even of a flexible option as having possibly severe repercussions in

${ }^{77}$ See Y. Dezalay/B. Garth, 'The Import and Export of Law and Legal Institutions: International Strategies in National Palace Wars', in D. Nelken and J. Feest (eds.), Adapting Legal Cultures (Hart Publishing, 2001); K. Pistor, 'The Standardization of Law and Its Effect on Developing Economies', (2002) 50 American Journal of Comparative Law 97 ff.; D. Berkowitz/K. Pistor/J.-F. Richard, 'Economic Development, legality, and the transplant effect', (2003) 47 European Economic Review 165-195. See in general A. Watson, Legal Transplants. An Approach to Comparative Law (Scottish Academia Press, 1974); W. Ewald, 'How does it feel to try a rat?' (1995) 143 U. Pa. L. Rev. 1889-2149; P. Legrand, 'The Return of the Repressed: Moving Comparative Legal Studies Beyond Pleasure', (2001) 75 Tulane Law Review 1033-1051.

${ }^{78}$ See, for example, .

${ }^{79}$ Teubner (2001), supra; G. Teubner, 'Eigensinnige Produktionsregimes: Zur Ko-evolution von Wirtschaft und Recht in den varieties of capitalism', (1999) 5 Soziale Systeme 7-25.

${ }^{80}$ Hereto: M. Henssler, 'Unternehmerische Mitbestimmung in der Societas Europea. Neue Denkanstöße für die "Corporate Governance"-Diskussion', in M. Habersack,P. Hommelhoff,U. Hüffer and K. Schmidt (eds.), Festschrift für Peter Ulmer zum 70. Geburtstag am 2. Januar 2003 (De Gruyter Recht, 2003); B. Keller, 'The European company statute: employee involvement - and beyond', (2002) 33 Industrial Relations Journal 424-445. 
the receiving legal culture. ${ }^{81}$ The idea of co-evolution further not only suggests unpredictable effects or even serious irritations in the receiving specific disciplinary or doctrinal area. In addition, coevolution will unfold in that the adaptation of the legal system to a particular rule will not be confined to the specific area, but the legal system's adaptation is likely to have effects on the development of embedding, neighbouring systems. ${ }^{82}$ Among the neighbouring fields of corporate law, which will be particularly sensitive to changes in the corporate law régime, we find, for example, employment law, the norms governing industrial relations, and the rules of securities regulation. But, this wider perspective on the irritating, chaotic and non-linear, unpredictable effects of harmonisation ${ }^{83}$ again sheds light not only on the complex conditions of European company law making. It also underscores the intricate dynamics that characterise legal development as such.

A systems theory-based, evolutionary approach to studying the process of European company law harmonisation is likely to produce valuable insights into the dynamics of harmonising legal cultures and into the problems resulting from national differences, but also from the chaotic effects that any rule introduction is likely to have within a particular legal culture. In rejecting the idea that law might be-when exposed to and implicated in a process of system competition-spontaneously gravitating towards uniform solutions, an alternative vision of the alleged bifurcation between harmonisation and regulatory competition might emerge.

\footnotetext{
${ }^{81}$ See Andreas Nölting, 'Warten bis der Dachstuhl brennt', (2004) Manager Magazin, 16 November 2004, interviewing Professor Michael Adams, who recognizes the German codetermination regime as an obstacle to German companies' attractiveness and competitiveness.

${ }^{82}$ Teubner (2001), supra.

${ }^{83}$ L. Enriques, 'Company Law Harmonization Reconsidered: What Role for the EC?' (2005) ECGI Law Working Paper No. 53/2005 (November) http://ssrn.com/abstract=850005, 20: "Complexity, obscurity and uncertainty..."
} 
Instead of accounting for harmonisation successes and failures with an exclusively quantitative measure, this approach invites a closer analysis of the multilevel and poly-contextual evolutionary processes set off by legal initiatives, policy instruments, or court decisions.

In fact, European company law has a significance that decisively transcends company law as such. Researching the genesis and the fate of various Community directives in the field of company law improves our general understanding of different legal systems in Europe. It is in this light that EU law scholars have increasingly highlighted the importance of European learning processes ${ }^{84}$ often associated now with the Open Method of Co-ordination. ${ }^{85}$ Our understanding of these legal systems, and of company law systems in particular, is likely to be increasingly informed by a richer assessment of these legal systems and of the rules and standards in a specific field. From a perspective that also includes the historical trajectories, the political constellations at different times of the system's particular development, and the wider socio-economic embeddedness of a specific legal system, we recognise that, indeed, our focus on company law tout court et tout près must be widened in order to better understand the forces that drive this development. This development is, for the time being, only partly and, it seems, inadequately depicted by notions of convergence or divergence, harmonisation, unification, or regulatory competition. These concepts themselves, while regularly being studied with regard to their costs, benefits, and alternatives, in fact tell us little

84 S. Deakin, 'Regulatory Competition versus Reflexive Harmonisation in European Company Law', in D. C. Esty and D. Geradin (eds.), Regulatory Competition and Economic Integration. Comparative Perspectives (Oxford University Press, 2001); C. Barnard/S. Deakin, 'Corporate governance, European governance and social rights', in B. Hepple (eds.), Social and Labour Rights in a Global Context (Cambridge University Press, 2002).

${ }^{85}$ Hereto, see D. Hodson/I. Maher, 'The Open Method as a New Mode of Governance: The Case of Soft Economic Policy Coordination', (2001) 39 Journal of Common Market Studies 719-746; J. Scott/D. Trubek, 'Mind the Gap: Law and New Approaches to Governance in the European Union', (2002) 8 European Law Journal 1-18. 
about the underlying processes of norm evolution, which they purport to explain.

Of course, critique of regulatory competition has long been exercised. Lucian Bebchuk very rightly remarked, some years ago, in a simple, straightforward language, that whereas state competition furthered interests in some respects, it did so only with regard to a specific type of interests. In contrast, 'state competition', he wrote, failed to enhance issues of 'significantly re-distributive' quality, issues that directly affect the strength of market discipline, and, lastly, issues that implicate the interests of not only shareholders and managers but also third parties. ${ }^{86}$

What is needed, it seems, is an approach to overcome the constantly recurring deadlock between these confronting approaches of unification versus regulatory competition. As we saw, the long and painful history of trying to harmonise European company law can serve as a strong illustration. ${ }^{87}$ These experiences underscore what scholars of European governance have been suggesting all along: that we need to rethink the troubling pair of 'negative and positive integration' from another, perhaps wider angle. ${ }^{88}$ One of the more promising suggestions in this regard

86 L. A. Bebchuk, 'Federalism and the Corporation: The Desirable Limits on State Competition in Corporate Law', (1992) 105 Harvard Law Review 1437-1510; see for a restatement of the argument: L. A. Bebchuk/A. Ferrell, 'Federalism and Takeover Law: The Race to Protect Managers from Takeovers', in D. C. Esty and D. Geradin (eds.), Regulatory Competition and Economic Integration. Comparative Perspectives (Oxford University Press, 2001)

${ }^{87}$ R. Buxbaum/K. J. Hopt, Legal Harmonization and the Business Enterprise. Corporate and Capital Market Law Harmonization Policy in Europe and the U.S.A. (Walter de Gruyter, 1988); E.-M. Kieninger, Wettbewerb der Rechtsordnungen im Europäischen Binnenmarkt (Mohr Siebeck, 2002); S. Lombardo, Regulatory Competition in Company Law in the European Community. Prerequisites and Limits (Peter Lang, 2002); H. Eidenmüller, 'Wettbewerb der Gesellschaftsrechte in Europa (Besprechung des EuGH-Urteils "Überseering")', (2002) 23 ZIP 2233-2245;

88 See, e.g., Scharpf, European Governance, supra; M. Jachtenfuchs, 'The Governance Approach to European Integration', (2001) 39 Journal of Common Market Studies 245-264; 
seems to be to re-imagine legislative and regulatory competition as a procedural enterprise, a learning experience of dealing with different to incompatible norms and institutions. Certainly, theorising of regulatory competition has pointed to the experimentative and innovative potential of regulatory competition in de-centred regulatory spheres all along. ${ }^{89}$

\section{B Reflexive Governance in European Company Law}

While harmonisation aims at overcoming the disparate tendencies of national or regional political economies by pointing out the advantages of unifying and levelling existing differences, the idea of regulatory competition recognises the all-decisive potential of the market as a process of discovery and of elimination..$^{90}$ While harmonisation is likely to come from the top or the centre, regulatory competition unfolds allegedly primarily in the horizontal. Neither of these rough characterisations certainly succeeds in capturing the more sophisticated realisations of these paradigms. Regulatory competition can certainly integrate the idea of differently legitimated political actors as well as that of a hierarchy of norms. Harmonisation, then, can also encompass elements ranging from the poles of unification to approximation, in between allowing for adaptation and mutual learning.

Indeed, we find signs that the all-or-nothing opposition of harmonisation and regulatory competition does not even seem to

D. Hodson/I. Maher, 'The Open Method as a New Mode of Governance: The Case of Soft Economic Policy Co-ordination', (2001) 39 Journal of Common Market Studies 719-746.

${ }^{89}$ See, ; C. Engel/K. H. Keller (eds.), Governance of Global Networks in the Light of Differing Local Values (Nomos, 2000); R. P. Appelbaum/W. F. Felstiner/V. Gessner (eds.), Rules and Networks. The Legal Culture of Global Business Transactions (Hart Publishing, 2001); R. D. Cooter, 'Against Legal Centrism. Review of Robert C. Ellickson, Order Without Law. How Neighbors Settle Disputes', (1993) 81 California Law Review 417-429.

${ }^{90}$ See the brllant discussion by E.-M. Kieninger, Wettbewerb der Rechtsordnungen im Europäischen Binnenmarkt (Mohr Siebeck, 2002), § 4. 
find a basis in the Community's institutional and programmatic history. A reconsideration of the Commission's 1985 White Paper on Completing the European Market, which accommodated different interests within the framework of a single legal measure ${ }^{91}$ makes it appear compatible with contemporary assessments of the potential of reflexive law to overcome integration obstacles. In this vein, Simon Deakin has convincingly argued for a reflexive approach to European (corporate) law development in order to take into account the persisting differences among EU Member States' systems of corporate law in order to allow for mutual learning processes in the context of European lawmaking. ${ }^{22}$ Building on these arguments, Forstinger has noted that '[m]inimum standards are seeking to promote diverse, local-level approaches to regulatory problems by creating a space for autonomous solutions to emerge'. ${ }^{\prime 3}$

\section{IIIRegulatory Change and the Role of Law}

Beyond this assessment, which is reflected in parallel discussions regarding future prospects of European harmonisation programmes, ${ }^{94}$ lies a subtle theoretical appraisal of the harmonisation processes that ties this debate back to debates over law reform and regulatory change. The paradigm of reflexive law, originally developed in response to regulatory deadlock resulting

${ }^{91}$ See Completing the Internal Market: White Paper from the Commission to the European Council, $\operatorname{COM}(85) 310$ final, http://europa.eu.int/comm/off/pdf/1985_0310_f_en.pdf available at

${ }^{92}$ Deakin, supra, at 211.

${ }^{93}$ C. M. Forstinger, TAKEOVER LAW IN the EU AND the USA. A COMPARATIVE ANALYSIS (KLUWER LAW INTERNATIONAL, 2002), at 159.

${ }_{94}$ M. Dougan, 'Minimum Harmonization and the Internal Market', (2000) 37 Common Market Law Review 853-885 (describing the move from Single Market harmonization policy to the integration of more policy objectives through consecutive treaties since 1986). 
from political pressure against juridification in the 1970s and early $1980 \mathrm{~s},{ }^{95}$ has received increased recognition in present international debates. This recognition has occurred in the context of European integration ${ }^{96}$ and corporate law regulation, ${ }^{97}$ as well as that of environmental law $^{98}$ and sustainable development. ${ }^{99}$ At present, reflexive law unfolds in an even more intricate manner, as comparative views on legal transplantation often fail to capture the co-evolutionary processes that unfold in a given legal, social, and political order when legal transplantation takes place. As argued above, rather than a mere integration into another legal order, legal transplantation unfolds as a sophisticated process of interaction and confrontation between the imported instrument

${ }^{95}$ See K. Günther, 'Der Wandel der Staatsaufgaben und die Krise des regulativen Rechts', in D. Grimm (eds.), Wachsende Staatsaufgaben - sinkende Steuerungsfähigkeit des Rechts (Nomos, 1990); G. Teubner, 'Juridification - Concepts, Aspects, Limits, Solutions', in G. Teubner (eds.), Juridification of Social Spheres (Walter de Gruyter, 1987); G. Teubner, 'Reflexives Recht', (1982) 68 ARSP 13-59; R. Wiethölter, 'Materialization and Proceduralization in Modern Law', in G. Teubner (eds.), Dilemmas of Law in the Welfare State (Walter de Gruyter, 1986).

${ }^{96}$ See M. Dougan, 'Vive la Différence? Exploring the Legal Framework for Reflexive Harmonisation Within the Single European Market', in R. A. Miller and P. Zumbansen (eds.), Annual of German \& European Law, Vol. I (2003) (Berghahn Books, 2004).

${ }^{97}$ Deakin, supra, at 211-13; Forstinger, supra, at 158-69. Forstinger states: "This approach uses both centralized regulation of minimum standards to overcome market failures, existing specifically in the area of takeovers, and some degree of self-regulation to preserve space for autonomous governance at member state level." Id. at 158 . He continues, "The aim of reflexive harmonization is to protect the diversity of national legal systems, while at the same time seeking to channel the process of evolutionary adaption of rules at state level." Id. at 160 .

${ }^{98}$ See E. Orts, 'Reflexive Environmental Law', (1995) 89 Northwestern University Law Review 1227-1340; K.-H. Ladeur, Das Umweltrecht der Wissensgesellschaft (Duncker \& Humblot, 1995); O. Perez, Ecological Sensitivity and Global Legal Pluralism. Rethinking the Trade and Environment Conflict (Hart Publishing, 2004); .

${ }^{99}$ See Peter Cornelius \& Bruce Kogut, Creating the Responsible Firm: In Search for a New Corporate Governance Paradigm, 4 GERMAN L.J. 45 (2003), available at http://www.germanlawjournal.com/pdf/Vol04No01/PDF_Vol_04_No_01_45-52_Private_C ornelius_Kogut.pdf; . 
and other regulatory elements within the receiving system. As an imported legal standard is introduced into the receiving legal order, other social systems, each with their own internal dynamics, are likely to be irritated by this import. ${ }^{100}$ This perspective ultimately illuminates the tenacity displayed by different systems during the process of European integration while, at the same time, helping us better understand the complex interplay of legal reform and cultural and social systems. This is particularly important, as the process of European company law making continues to be increasingly influenced by changes in the law of corporate goverance elsewhere in the world. ${ }^{101}$ The international debate over convergence and divergence of corporate governance régimes ${ }^{102}$ develops in at least two critical dimensions that have yet to gain sufficient recognition within mainstream scholarship on corporate law and that have important repercussions on the further development of European company law. One of these dimensions concerns the changes that are taking place with regard to the evolution of corporate law through a combination of private norm-generation through different

${ }^{100}$ G. Teubner, 'Legal Irritants: How Unifying Law Ends Up In New Divergences', in P. A. Hall and D. Soskice (eds.), Varieties of Capitalism. The Institutional Foundations of Comparative Advantage (Oxford University Press, 2001).

101 See, e.g., C. Kirchner/R. W. Painter, 'Takeover Defenses under Delaware Law, the Proposed Thirteenth EU Directive and the New German Takeover Law: Comparison and Recommendations for Reform', (2002) 50 American Journal of Comparative Law 451-476.

${ }^{102}$ C. Crouch/W. Streeck, 'Introduction: The Future of Capitalist Diversity', in C. Crouch and W. Streeck (eds.), Political Economy of Moden Capitalism. Mapping Convergence and Diversity (Sage, 1997); H. Hansmann/R. Kraakman, 'The End of History for Corporate Law', (2001) 89 Geo. L. J. 439-468; M. O'Sullivan, 'The political economy of comparative corporate governance', (2003) 10 Rev. Int'l Pol. Econ. 23-72; W. W. Bratton/J. A. McCahery, 'Comparative Corporate Governance and Barriers to Global Cross Reference', in J. A. McCahery,P. Moerland,T. Raaijmakers and L. Renneborg (eds.), Corporate Governance Regimes. Convergence and Diversity (Oxford University Press, 2002); J. N. Gordon/M. J. Roe (eds.), Convergence and Persistence in Corporate Governance (Cambridge University Press, 2004). 
methods of self-regulation and formal legislation. ${ }^{103}$ The radical changes to the process of lawmaking, through the emergence of corporate governance codes, codes of conduct, and recommendations of best practice that have evolved in Germany ${ }^{104}$ and other countries, ${ }^{105}$ as well as in international institutions, ${ }^{106}$ have an important bearing on our future assessment of corporate law from a comparative perspective. The second, crucial dimension, ripe for review by contemporary corporate governance scholars, deals with the economic pressure experienced by mature industrial and post-industrial states to develop innovative means for economic and corporate growth. While this need may seem

\footnotetext{
${ }^{103}$ An important example is the German Corporate Governance Code, which was conceptualized and prepared by two government commissions between 2000 and 2002. This code provides corporate actors with a concise account and description of German corporate governance and offers recommendations for corporate behavior. German Corporate Governance Code, http://www.corporate-governance-code.de/index-e.html; see T. Baums, 'Interview: Reforming German Corporate Governance: Inside a Law Making Process of a very new nature', (2001) 2 German Law Journal at: http://www.germanlawjournal.com/past_issues.php?id=43 [hereinafter Baums, Interview]; T. Baums, 'Company Law Reform in Germany', (2003) 3 J. Corp. L. Stud. 181-189.
}

104 See Baums, Interview, supra; T. Baums (eds.), Bericht der Regierungskommission Corporate Governance. Unternehmensführung, Unternehmenskontrolle, Modernisierung des Aktienrechts (Otto Schmidt, 2001); P. Zumbansen, 'The Privatization of Corporate Law? Corporate Governance Codes and Commercial Self-Regulation', (2002b) Juridikum 136145 .

${ }^{105} \mathrm{~A}$ instructive assessment of the UK is provided in B. R. ChefFins, COMPANY LAW. THEORY, StRUCTURE AND OPERATION (CLARENDON PRESS, 1997). For theoretical background, see R. Baggott, 'Regulatory Reform in Britain: The Changing Face of SelfRegulation', (1989) 67 Public Administration 435-454; J. Black, 'Constitutionalising SelfRegulation', (1996) 59 Modern Law Review 24.

${ }^{106}$ See, e.g., the Corporate Governance Principles issued by the OECD, available at http://www.oecd.org; see also Carolin F. Hillemanns, UN Norms on the Responsibilities of Transnational Corporations and other Business Enterprises with regard to Human Rights, 4 GERMAN L.J. 1065 (2003) (for a development in international corporate social responsibility), available

http://www.germanlawjournal.com/pdf/Vol04No10/PDF_Vol_04_

No_10_1065-1080_European_Hillemanns.pdf 
almost painfully commonplace, ${ }^{107}$ its realisation, in the context of radically interconnected markets and immense pressure on local and transnational spheres of production, ${ }^{108}$ constitutes a pivotal issue for contemporary comparative scholars working with corparate governance. ${ }^{109}$ European company law and a closer look at the dynamics and tensions continuously unfolding in this field thus becomes a part and a starting point into a wider research into the contemporary political economy of governance through law in a globally integrating world.

\section{A Harmonization, Competition and Integration as Narratives}

Let us finally return to the role of law in the development of European company law. Our challenge remains to unfold the wealth of dimensions inherent to the regulatory and normative vocabulary with which we engage in our contemporary critique of regulatory competition. The distinction between regulatory competition and harmonisation, regardless of how mitigated and tamed the former, how sophisticated and principled the latter-

\footnotetext{
107 See Reinventing Europe: Innovation: With so much of its industrial base ageing and resistant to change, how can Europe close the research and development gap with America?, The ECONOMist TeChNOLOGy QUARTERLY, Sept. 6, 2003, at 28, available at 2003 WL 58583964.

108 See J. R. Hollingsworth, 'New perspectives on the spatial dimensions of economic coordination: tensions between globalization and social systems of production', (1998) 5 Review of International Political Economy 482-507; K. Ibata-Arens, 'The comparative political economy of innovation', (2003) 10 Review of International Political Economy 147165 .

109 See M. O'Sullivan, 'The innovative enterprise and corporate governance', (2000) 24 Cambridge Journal of Economics 393-416; W. W. Powell, 'The Capitalist Firm in the Twenty-First Century: Emerging Patterns in Western Enterprise', in P. Dimaggio (eds.), The Twenty-First-Century Firm. Changing Economic Organization in international Perspective (Princeton University Press, 2001); P. Zumbansen, Innovation und Pfadabhängigkeit. Das Recht der Unternehmensverfassung in der Wissensgesellschaft (Habilitation thesis, University of Frankfurt) forthcoming).
} 
this distinction does not allow us to understand why a certain outcome might be a good one. Indeed, the debate over regulatory competition versus harmonisation does not by itself open a normative dimension, as it does not provide an adequately rich account or foundation on which to ask whether the outcome was 'good'. The answer, however, is existential in light of the evergrowing integration of worldwide activity and the hyper-sped collision of different experiences and value systems. ${ }^{110}$

Only a thorough assessment of the intricate history (call it narratives) and challenges of national governance experiences (call them administrative and constitutional law) can shed light on the interests as well as the lingering hopes as well as the remembered or repressed frustrations that tacitly but still very powerfully shape any form of political interaction. The examples of law reform touched upon in this article provide rich material evidence for the complexity of international integration and system competition. In order, however, to unfold a richer dimension of regulatory processes (competition, coordination, interaction etc.), we need to include our assessment of changes in lawmaking, the transformation and hybridisation of formerly public governance, the proliferation of laws, codes of conducts, conventions into our exercise of rethinking regulatory action. Only here can we trace the journeys that notions and terms central to our conceptualising take throughout history and how they perform in times of challenge. The picture on regulatory competition, then, changes dramatically: not only do governments (or parts or different levels of government) compete and certain sets of rules, but whole legal, social, political and economic cultures, their current states and their historical narratives compete.

\footnotetext{
${ }^{110}$ P. B. Stephan, 'Regulatory cooperation and competition: the search for virtue', in G. A. Bermann,M. Herdegen and P. L. Lindseth (eds.), Transatlantic Regulatory Co-operation (Oxford University Press, 2000); J. Trachtman, 'Regulatory Competition and Regulatory Jurisdiction', (2000) 3 Journal of International Economic Law 331.
} 
The study of Europe's unique history and experience of 'integration through law' ${ }^{\prime 11}$ points to an intricate interplay between succeeding, overlapping and repeating phases of competing policies of building a peaceful union, an economic, a political union. ${ }^{112}$ These terms hardly capture the wealth of political imagination that has gone into and continues to inform European integration, and what is more, they might be misleading in their respective exclusiveness and totality. ${ }^{113}$ They do, however, already suffice to call into question the conceptual pair of harmonisation and regulatory competition when applied to explain and to illuminate the manifold faces of Europe's search of 'meaning and purpose'. ${ }^{114}$ With a view to the degrees of European and international cooperation and coordination that have been characterised as multilevel governance, ${ }^{115}$ one could be tempted to argue for a move from harmonisation and competition on to different degrees of regulatory coordination, cooperation, or

111 Haltern (2004), supra note 14; R. Buxbaum/K. J. Hopt, Legal Harmonization and the Business Enterprise. Corporate and Capital Market Law Harmonization Policy in Europe and the U.S.A. (Walter de Gruyter, 1988); J. H. H. Weiler, 'A Constitution for Europe? Some Hard Choices', (2002) 40 Journal of Common Market Studies 563-580.

112 E. Stein, 'International Integration and Democracy: No Love at First Sight', (2001) 95 American Journal of International Law (A.J.I.L.) 489-534; C. Landfried, Das politische Europa. Differenz als Potential der Europäischen Union (Nomos, 2002); I. Ward, 'Europe in Search of 'Meaning and Purpose", in K. Nuotio (eds.), Europe in Search of 'Meaning and Purpose' (Faculty of Law, University of Helsinki, 2004); H. Lindahl, 'European Integration: Popular Sovereignty and a Politics of Boundaries', (2000) 6 European Law Journal 239-256.

113 J. H. H. Weiler, 'The Transformation of Europe', (1991) Yale Law Journal 2403-2483.

114 See, in particular, Ward, Bankowski, and Gerstenberg in Nuotio (ed.), Europe in Search of 'Meaning and Purpose' (University of Helsinki, 2004).

115 See, e.g, I. Bache/M. Flinders (eds.), Multi-level Governance (Oxford University Press, 2004); F. W. Scharpf, 'European Governance: Common Concerns vs. the Challenge of Diversity', in M. Jachtenfuchs and M. Knodt (eds.), Regieren in internationalen Organisationen (Leske \& Budrich, 2002); W. Kerber/K. Heine, 'Zur Gestaltung von MehrEbenen-Rechtssystemen aus ökonomischer Sicht', in C. Ott and H.-B. Schäfer (eds.), Vereinheitlichung und Diversität des Zivilrechts in transnationalen Räumen (Mohr Siebeck, 2002). 
interaction to overcome the above described shortcomings in the concepts of competition and harmonisation. Yet, a mere substitution of the diametric scheme of regulatory competition versus harmonisation by a model of 'regulatory interaction' might still fall short of unfolding a comprehensive description of processes of international and transnational integration. The reasons for this are easier to find than an answer to our question of how to fruitfully complement or even to overcome the pair of harmonisation/competition. Concepts such as harmonisation, regulatory competition, and regulatory interaction seem to share a striking shortcoming in that they remain too exclusively centred on specific premises of regulation in the first place. The starting point of the preceding discussion therefore was the contestation of actor-centred premises that would inform a programme of regulatory interaction, and that could also be said to lie behind the known approaches to harmonisation and regulatory competition. ${ }^{116}$ In order to further explore and, ultimately, to reconsider these approaches within a wider regulatory framework of the law of corporate governance, we need to study the changing face of regulation as such. This will eventually allow us to place the inquiry into the prospects of European company law in a larger context of regulatory developments, not only on the European level, but also on the Nation State level and globally. ${ }^{117}$ A central tenet of this article has been that we need to assess the chances of border-crossing regulatory régimes such as European company law as part of a transnational law of corporate governance against the background of regulatory transformations inside and outside of the Nation State.

\footnotetext{
116 See, for example, the analysis by K. Heine/W. Kerber, 'European Corporate Laws, Regulatory Competition and Path Dependence', (2002) 13 European Journal of Law and Economics 47-71.

${ }^{117}$ D. Levi-Faur, 'The Global Diffusion of Regulatory Capitalism', (2004) 598 The Annals of The American Academy of Political and Social Science 12-29.
} 
We are well advised to carefully trace the changes of both actors and actions as they can be observed in complex, contemporary regulatory environments. In short: where we see a continuing erosion of the conceptual boundaries between the (political, interventionist, welfare, post-regulatory, supervision) state and (allegedly a-political) market, we begin to question the applicability and translatability of our concepts of state/market and public/private in the realm of transnational regulation. ${ }^{118}$ It is only through the observation of this repetition of the public/private distinction inside and outside of the Nation State that we may learn more about the chances of regulatory politics in a dramatically de-centralised, global knowledge economy. This has repercussions on our understanding of regulatory instruments and spaces. While these instruments (laws, directives, decisions, political programmes, codes of conduct) show a complex mix of hard and soft law, political intervention and self-regulation, the spaces and places of regulation become horizontally and vertically open. Regulation today takes place in many different spaces and on many different levels of norm-creation, increasingly challenging the fixture on the state as the sole author of binding norms. ${ }^{119}$ In this multilevel game of various public and private actors, traditional concepts of legitimacy have become as questionable as ideas of causation in contemporary tort law. It is here where we begin to understand the ways in which actors and authors occupy regulatory spaces that seem to follow rules that are less man-made than that they unfold from within the constant collision of heterogeneous functional imperatives as well as normative claims. From this perspective, then, our inquiry might add to a critical reassessment of the role and the nature of law itself.

\footnotetext{
118 For a more comprehensive discussion, see Peer Zumbansen, Transnational Law, in: Encyclopedia of Comparative Law (Jan Smits ed., Edward Elgar 2005).

119 J. N. Rosenau/E.-O. Czempiel, Governance without government: order and change in world government (Cambridge University Press, 1992).
} 


\section{B LAW'S BOUNDARIES?}

This would, however, move our inquiry well beyond the confines of the so-far described assessments of European company law. It would entail questions such as which role law can play in the facilitation of regulatory competition. What role can law play, if law itself were to be seen as no more than one particular social system whose function is to stabilise expectations? More importantly, and on a normative plane, what if law as a particular social system was just one among other systems, the rationalities of which constantly collide, and where the outcome might be far from any unification?

Perhaps, law ought to be understood as a social system whose function should be seen in allowing communicative meaning to survive from the battlefield of contemporary conflict into tomorrow's search for stability, certainty (and memory). Law can fulfil this stabilising function-despite, or should we say because of its relative autonomy from the rule-production that is otherwise taking place in the parameters of economic exchange or political discourse. Law's reproduction of meaning consists of capturing a specific, timely understanding of 'legal' as differentiated from 'illegal', without however allowing a larger societal discourse to set, shape, and further define this meaning and distinction of legal/illegal-against the tides of domestic and international conflict. Instead, law has an introverted tendency through which it develops rules and norms that are informed by yesterday's and today's definition and assignment of legal/illegal, and that will serve as guiding post and reminder when applied to conflict situations tomorrow. In a paradoxical moment of vulnerability and sovereignty over the concrete case, the law relies on its rules, which have been developed through repeated application in previous cases, and it is through this application today that the law constantly refines and improves its sensitivity for each new and different case. As such, law itself allows for an in-depth assessment of the various semantic heritages that are at work in 
our use of legal terms. ${ }^{120}$ At the same time, law competes with other narratives in making sense of the present regulatory challenges. In fact, it is only by way of engaging in an interdisciplinary inquiry that we can better understand the potential for law in this process. If it is true that legal terms, their history, and trajectory transport-even if in hidden form-the political aspirations and frustrations that accompanied their emergence or followed their failure, than a close look at our conceptions of governance might offer a promising way towards better assessing the chances of changing forms of political actionwithin and beyond Europe. ${ }^{121}$

\footnotetext{
${ }^{120}$ See only F. Cohen, 'Transcendental Nonsense and the Functional Approach', (1935) 35 Columbia Law Review 809-849; with regard to law as memory, see also P. Zumbansen, 'Das soziale Gedächtnis des Rechts, oder: Juristische Dogmatik als Standeskunst', in C. Joerges and G. Teubner (eds.), Rechtsverfassungsrecht. Recht-Fertigung zwischen Privatrechtsdogmatik und Gesellschaftstheorie (Nomos, 2003); and Haltern (2004), supra, 192.

${ }^{121}$ D. C. North, Institutions, Institutional Change and Economic Performance (Cambridge University Press, 1990): "The opportunities for political and economic entrepreneurs are still a mixed bag, but they overwhelmingly favor activities that promote redistributive rather than productive activity, that create monopolies rather than competitive conditions, and that restrict opportunities rather than expand them."
} 